CLINICAL STUDY

\title{
Glycosaminoglycans increase levels of free and bioactive IGF-I in vitro
}

\author{
Anne Vestergård Møller ${ }^{1,2}$, Søren Peter Jørgensen ${ }^{1}$, Jian-Wen Chen ${ }^{1,2}$, Anni Larnkjær ${ }^{3}$, Thomas Ledet ${ }^{2}$, \\ Allan Flyvbjerg ${ }^{1}$ and Jan Frystyk ${ }^{1}$ \\ ${ }^{1}$ Medical Research Laboratories, Clinical Institute and Medical Department M (Diabetes and Endocrinology) and ${ }^{2}$ Laboratory of Biochemical Pathology, \\ Aarhus University Hospital, Norrebrogade, DK-8000 Aarhus C, Denmark and ${ }^{3}$ LEO Pharma A/S, Industriparken 55, DK-2750 Ballerup, Denmark
}

(Correspondence should be addressed to J Frystyk; Email: jan@frystyk.dk)

\begin{abstract}
Background: It is unclear how IGFs become separated from their IGF-binding proteins (IGFBPs) in vivo. However, the IGFBPs possess binding sites for glycosaminoglycans (GAGs) and interaction with GAGs alters IGFBP ligand affinity. Accordingly, GAGs may control IGF bioavailability. To test this hypothesis, we investigated the effect of GAGs on serum levels of free and bioactive IGF-I, total IGF-I, and IGFBPs in vitro.

Methods: Serum was incubated with increasing concentrations of six different GAGs (heparin, tinzaparin (Innohep ${ }^{\circledR}$ ), dermatan sulfate, heparan sulfate, non-anticoagulant (nac) heparin, and nac low-molecular weight heparin). To investigate for reversibility, heparin was co-incubated with protamine sulfate (PS). Finally, the effect of heparin was studied in serum from pregnant and post partum women, normal subjects and patients with type 1 diabetes.

Results: All GAGs increased free IGF-I in a dose-dependent manner $(P<0.0001)$, whereas total IGF-I and IGFBP levels remained unchanged. However, the potency of the GAGs differed significantly $(P<0.0001)$ and did not relate to their anti-coagulating activity. The effect of heparin on free IGF-I was fully reversed by PS. Heparin increased free and bioactive IGF-I in all tested sera $(P<0.0001)$, but the increase was most pronounced in samples from pregnant women $(P<0.0001)$.

Conclusion: All tested GAGs stimulated the release of free and bioactive IGF-I in several types of serum, most likely by reversible interaction with the IGFBPs. The effect was most pronounced in pregnancy sera, which are characterized by extensive IGFBP-3 proteolysis. Our findings support the view that GAGs localized in the vessel wall and attached to the extracellular matrix control IGF-I tissue accessibility and bioactivity.
\end{abstract}

European Journal of Endocrinology 155 297-305

\section{Introduction}

The insulin-like growth factors (IGF-I and -II) are multipotent peptides affecting growth, differentiation, and apoptosis in virtually all cell types through endocrine, paracrine, and autocrine pathways $(1,2)$. In the circulation, only a minor fraction of IGF-I is free, while the majority is bound to one of six different high-affinity IGF-binding proteins (IGFBPs) forming binary complexes and ternary complexes with the nonIGF-binding glycoprotein acid labile subunit (ALS). The IGFBPs are able to stimulate as well as to inhibit IGF-I-mediated effects, and they also possess IGFI-receptor (IGF-IR)-independent effects (this particularly applies to IGFBP-3). ALS appears to affect IGFbioactivity by restraining circulating IGFs-I and -II within the blood stream, hereby limiting the access of the IGFs to the peripheral target tissues (3-8).
Glycosaminoglycans (GAGs) are relatively large molecules composed of polysaccharide side chains attached to a core backbone of protein, forming a proteoglycan. Each polysaccharide side chain consists of a disaccharide repeat unit composed of hexosamine linked to either iduronic or glucuronic acid. The hexosamine is a glucosamine in heparin, and heparin sulfate and a galactosamine in dermatan sulfate (DS). The disaccharide units are heavily modified and the number of modifications allows for a large structural and functional diversity; it is the composition of the disaccharide side chains that defines the individual GAGs (9).

The disaccharides are often heavily sulfated and hence strongly negatively charged, and this may explain the pronounced ability of the GAGs to interact with proteins such as growth factors, enzymes, and chemokines. In the body, GAGs are present in mast cells 
(as heparin), in the extracellular matrix (ECM) and attached to cell surfaces $(9,10)$. Clinically, GAGs are widely used for their anti-coagulating effects. Physiologically, the role of the GAGs has still to be fully determined. However, they are known to interact strongly with several growth factors, and therefore, GAGs are assumed to influence growth of normal as well as neoplastic cells $(9,10)$.

All IGFBPs except IGFBP-1 possess heparin-binding domains (HBDs) located near the C-terminal IGFbinding site. In addition, IGFBPs- 3 and -5 possess a HBD near the ALS-binding site $(4,11,12)$. It has been hypothesized that GAGs localized within the ECM or at cell surfaces through interaction with the HBD of the IGFBPs are able to liberate bound IGF-I and hence enhance IGF-I bioactivity at the local tissue level (13). It has also been suggested that GAGs localized at the vascular endothelium may regulate the passage of IGF-I to the tissues (14). However, at present, there are no available data on the effect of GAGs on levels of free or bioactive IGF-I.

The aim of the present study was to investigate the effect of several different GAGs with and without anticoagulating activity on serum levels of free IGFs-I and -II in vitro. In addition, we compared the effect of heparin on serum levels of free and bioactive IGF-I in different patient groups characterized by an abnormal IGFBPprofile and IGFBP-3 proteolytic activity.

\section{Materials and methods}

\section{Glycosaminoglycans}

All GAGs used in the present study were generously provided by LEO Pharma A/S (Ballerup, Denmark). They included unfractionated heparin (Hep, molecular weight $\left.\left(M_{\mathrm{w}}\right)=14.0 \mathrm{kDa}\right)$, unfractionated heparin chemically modified so that it was non-anticoagulant (nac-Hep, $M_{\mathrm{w}}=12.3 \mathrm{kDa}$ ), low-molecular tinzaparin (Innohep $^{\circledR}$, Tin, $M_{\mathrm{w}}=6.5 \mathrm{kDa}$ ), chemically modified tinzaparin devoid of any anti-coagulant activity (nac-Tin, $M_{\mathrm{w}}=5.3 \mathrm{kDa}$ ), DS (molecular peak, $M_{\mathrm{p}}=$ $35.5 \mathrm{kDa})$ and heparan sulfate (HS, $\left.M_{\mathrm{p}}=15.4 \mathrm{kDa}\right)$.

\section{Assays}

The immunological levels of IGFs-I and -II were determined by in-house monoclonal time-resolved immunofluorometric assays as previously described (15). All GAGs were examined for cross-reactivity in the IGF assays. However, none of the GAGs showed any detectable cross-reactivity at concentrations below $400 \mu \mathrm{mol} / \mathrm{l}$, which was the highest concentration used in the present study (a concentration of $400 \mu \mathrm{mol} / \mathrm{l}$ equals $50 \mathrm{U} / \mathrm{ml}$ heparin). Serum total IGFs-I and -II were determined in acid ethanol extracted serum with a within assay and between assay coefficient of variation (CV) averaging 5 and 10\% respectively (15). Serum free IGFs-I and -II were determined using ultrafiltration by centrifugation at approximate in vivo like conditions (16). Within and between assay CV values averaged $15-20 \%$.

Serum IGF-I bioactivity was determined by an in-house kinase receptor activation assay (KIRA) based on human embryonic renal cells (EBNA 293 from Invitrogen) transfected with the human IGF-IR gene (17). In this assay, cultured cells are stimulated with either IGF-I standards or unknown serum samples. After $15 \mathrm{~min}$ of stimulation, samples are removed and cells lysed. Then, crude cell lysates are transferred to an assay that detects the concentration of phosphorylated (i.e. activated) IGF-IRs. This assay uses a MAB against the extracellular domain of the IGF-IR for coating and a europium-labeled monoclonal anti-phosphotyrosine antibody (PY20) as tracer. The assay is sensitive (detection limit $<0.08 \mu \mathrm{g} / \mathrm{l}$ ), specific (IGF-II crossreactivity is $12 \%$, proinsulin, insulin, and insulin analogs have a cross-reactivity $<1 \%$ ), and precise (mean within and in-between assay $\mathrm{CV}$ values were $<7$ and $15 \%$ ) (17).

Intact IGFBPs were determined by Western ligand blotting (WLB) as previously described (18). The resulting autoradiographs yielded five distinct bands. On the basis of immunoreactivity and/or molecular size, these bands were tentatively identified as representing IGFBP-3, IGFBP-2, IGFBP-1, glycosylated IGFBP-4, and non-glycosylated IGFBP-4 (19).

\section{Study 1: effect of increasing doses of GAGs on serum free IGFs-I and -II}

To compare the potency of the different GAGs, six nonfasting serum samples from healthy subjects were added in increasing concentrations $(0,4,40$, and $400 \mu \mathrm{mol} / \mathrm{l})$ of one of the six different GAGs mentioned earlier. All GAGs were diluted in Krebs Ringer buffer (KRB) adjusted to $\mathrm{pH} 7.4$ with $\mathrm{CO}_{2}$ and added $5 \%(\mathrm{w} / \mathrm{v})$ human serum albumin (ICN Biomedical, Aurora, OH, USA). All serum samples $(2 \mathrm{ml})$ were added into the same volume of buffer $(200 \mu \mathrm{l})$. After addition of GAG, samples were equilibrated for $30 \mathrm{~min}$ at $37^{\circ} \mathrm{C}$, before they were centrifuged. Each sample was centrifuged in triplicates and the ultrafiltrates assayed for free IGFs-I and -II. In addition, samples were assayed for total IGFs-I and -II as well as IGFBPs levels. All samples from each of the six GAGs were assayed within the same run.

\section{Study 2: effect of protamine sulfate (PS) on heparin-treated serum}

PS (a polycation) has been shown to reverse the effect of heparin (which is heavily negatively charged) on ALS binding to IGFBP-3:IGF-I complexes (14). Therefore, we found it of interest to investigate whether PS was able to reverse the effect of heparin on serum free IGF-I. Pilot 
studies showed that the effect of $400 \mu \mathrm{mol} / \mathrm{l}$ heparin on free IGF-I was fully neutralized by the addition of $5 \mathrm{~g} / \mathrm{l}$ PS (data not shown). Thus, this dose was used in the next experiment, where heparin $(200 \mu \mathrm{l}, 400 \mu \mathrm{mol} / \mathrm{l}$ dissolved in KRB) was added to four non-fasting serum samples $(2 \mathrm{ml})$ which were incubated for $60 \mathrm{~min}$ at $37^{\circ} \mathrm{C}$. PS (dissolved in KRB) was added at variable time points; at the beginning of the incubation ( $0 \mathrm{~min}$ ), after 15 and $30 \mathrm{~min}$, and immediately before ultrafiltration (after $60 \mathrm{~min}$ ). Untreated serum samples served as controls; the same volume of KRB was added to all samples. After ultrafiltration, all samples were assayed for free IGF-I.

\section{Study 3: effect of heparin on serum free and bioactive IGF-I in vitro}

Before comparing the effect of GAGs on serum levels of free and bioactive IGF-I, pilot studies using six non-fasting serum samples were performed, evaluating different KIRA incubation lengths $(15,30$, and 60 min at $37^{\circ} \mathrm{C}$ ), different GAGs (Hep, Tin, DS, and HS) and increasing doses $(0,4,10,40,100$, and $400 \mu \mathrm{mol} / \mathrm{l})$ (data not shown). In brief, these pilot experiments showed that Hep and HS were the most potent stimulators of IGF-I bioactivity in vitro. Furthermore, the KIRA signal was relatively stable within the tested time interval, and therefore it was decided to incubate the KIRA for $30 \mathrm{~min}$. Finally, addition of $40 \mu \mathrm{mol} / \mathrm{l}$ heparin gave a signal well within the range of the KIRA calibration curve. Thus, all further measurements of serum-free and bioactive IGF-I were carried out with a heparin concentration of $40 \mu \mathrm{mol} / \mathrm{l}$ and a KIRA cell incubation length of $30 \mathrm{~min}$.

The effect of heparin on levels of free and bioactive IGF-I was investigated in four different study groups, comprising ten healthy women studied twice; during pregnancy (gestation week 24-28) and at 5 weeks post partum, ten type 1 diabetic patients (T1DM) and ten controls matched with the diabetic patients (Table 1). All sera were diluted 1:20 in KRB with or without heparin $(40 \mu \mathrm{mol} / \mathrm{l})$ prior to the assessment of free and bioactive IGF-I. The serum samples used in this study originate from previously described larger study cohorts
$(20,21)$. All samples were collected in accordance with the Declaration of Helsinki after informed consent.

\section{Statistical analysis}

Data are given as mean \pm s.e.M. Paired differences within more than two groups were tested by repeated measures one-way ANOVA followed by Student's NewmanKeuls's test for multiple comparisons or Bonferroni's $t$-test when appropriate. Unpaired differences within more than two groups were tested by ANOVA followed by Student's Newman-Keuls's test for multiple comparisons. Comparisons between two groups were performed by Student's paired or unpaired t-test or by paired (Wilcoxon's) or unpaired (Mann-Whitney's) rank sum test when appropriate. Linear regression analysis was used to assess biological associations between serum levels of total, free, and bioactive IGF-I. All data were log transformed prior to statistical analysis.

\section{Results}

\section{Study 1}

In this experiment, six non-fasting sera from healthy controls were used. The baseline levels of free IGFs-I, -II, total IGFs-I, and -II averaged 1.71 \pm 0.35 , $1.63 \pm 0.11,222 \pm 38$, and $952 \pm 81 \mu \mathrm{g} / \mathrm{l}$ respectively.

All GAGs increased levels of free IGF-I in a dosedependent manner $(P<0.0001$; Fig. 1), however, with different potency $(P<0.0001)$. nac-Hep, HS and Hep were similarly potent, increasing free IGF-I by $933 \pm$ $130,628 \pm 60$, and $620 \pm 52 \%$ respectively, at the highest dose, when compared with baseline. These increases were higher than those observed after addition of Tin $(289 \pm 53 \%)$ and nac-Tin $(268 \pm 17 \%)$. DS was the least potent, increasing free IGF-I by $173 \pm$ $10 \%$ above baseline. The GAGs also affected free IGF-II in a dose-dependent manner and with different potencies $(P<0.0001$; Fig. 2$)$. At the highest dose, the greatest increments in free IGF-II were observed after nac-Hep $(619 \pm 49 \%)$ and Hep $(532 \pm 89 \%)$, being significantly higher than those observed after addition of HS $(319 \pm 36 \%)$, Tin $(245 \pm 23 \%)$, and nac-Tin

Table 1 The four study groups and their baseline levels of total, bioactive, and free insulin-like growth factor-I (IGF-I). Data are presented as mean \pm S.E.M. or numbers.

\begin{tabular}{|c|c|c|c|c|c|c|}
\hline Study group & $\begin{array}{c}\boldsymbol{n} \text { and gender } \\
\left(\$ / 0^{*}\right)\end{array}$ & Age (years) & BMI $\left(\mathrm{kg} / \mathrm{m}^{2}\right)$ & Total IGF-I $(\mu \mathrm{g} / \mathrm{l})$ & $\begin{array}{l}\text { Bioactive IGF-I } \\
(\mu \mathrm{g} / \mathrm{l})\end{array}$ & Free IGF-I $(\mu \mathrm{g} / \mathrm{I})$ \\
\hline Pregnant women & $10 / 0$ & $27.3 \pm 1.0$ & $22.8 \pm 2.6$ & $192 \pm 17$ & $2.53 \pm 0.31^{*}$ & $1.07 \pm 0.14^{*}$ \\
\hline $\begin{array}{l}\text { Post partum } \\
\text { women }\end{array}$ & $10 / 0$ & & $24.8 \pm 1.0$ & $189 \pm 12$ & $1.14 \pm 0.10$ & $0.52 \pm 0.07$ \\
\hline $\begin{array}{l}\text { Type } 1 \text { diabetes } \\
\text { (T1DM) }\end{array}$ & $8 / 2$ & $34.1 \pm 2.4$ & $24.2 \pm 0.8$ & $89 \pm 15^{\star}$ & $0.77 \pm 0.13^{\star}$ & $0.29 \pm 0.09^{*}$ \\
\hline Controls & $8 / 2$ & $32.8 \pm 2.3$ & $23.0 \pm 0.4$ & $132 \pm 13$ & $1.15 \pm 0.09$ & $0.37 \pm 0.04$ \\
\hline
\end{tabular}

${ }^{\star} P<0.05$ when comparing pregnant women and post partum women (paired analyses), or when comparing controls and patients with T1DM (unpaired analyses). For all four study groups, levels of bioactive IGF-I were significantly higher than those of free IGF-I $(P<0.0001)$. 

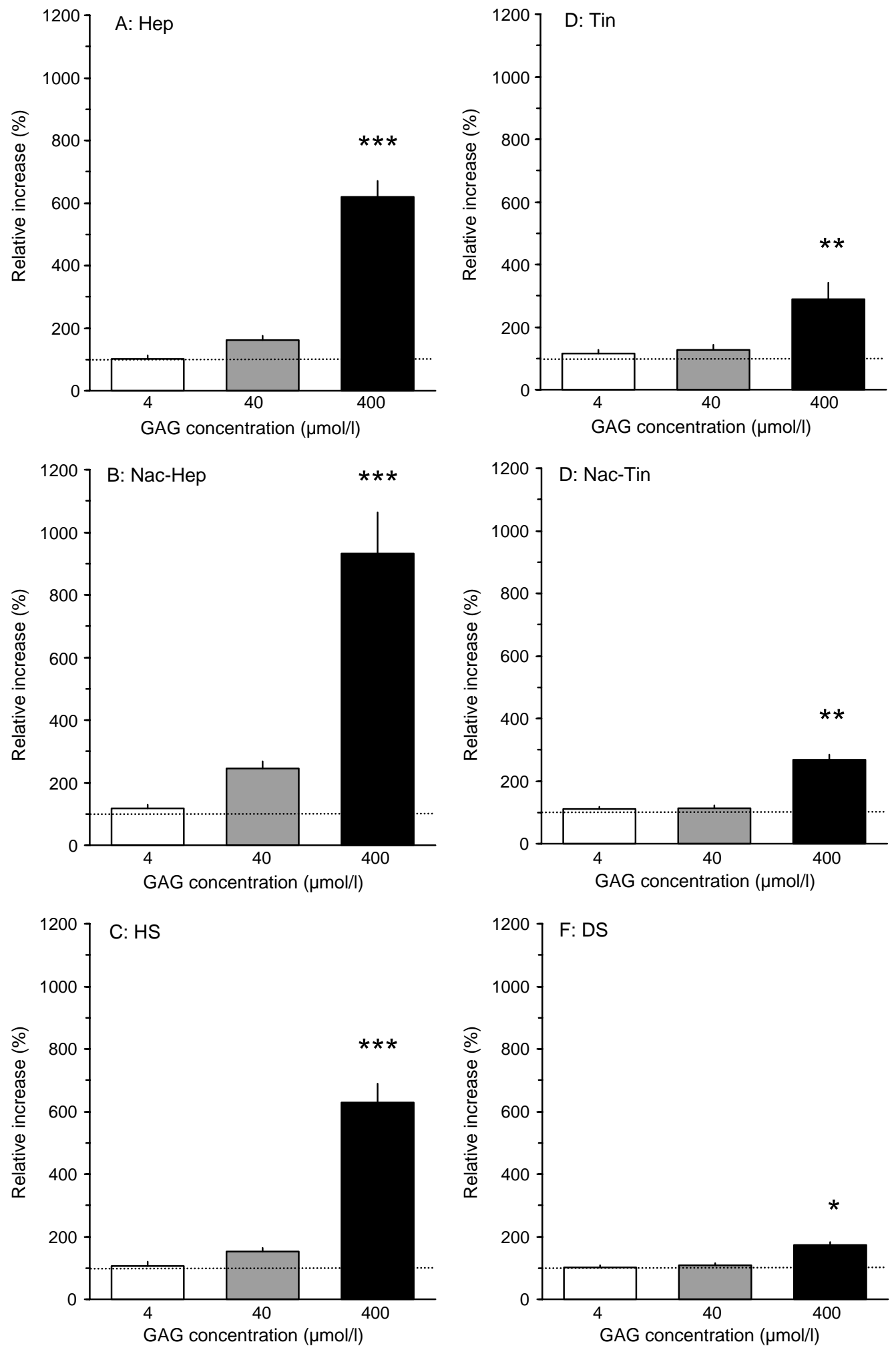

Figure 1 The relative increases in serum-free IGF-I after addition of six different glycosaminoglycans (GAGs). The dotted lines represent baseline levels after addition of buffer $(\sim 100 \%)$. All GAGs dose-dependently increased levels of free IGF-I $(P<0.0001)$, however, with different potency $(P<0.0001)$ : at the highest doses, Hep, nac-Hep and HS $\left(^{* * *}\right)$ increased free IGF-I more potently than Tin and nac-Tin $\left({ }^{* \star}\right)$, which both increased free IGF-I more potently than DS $\left(^{*}\right)$. 

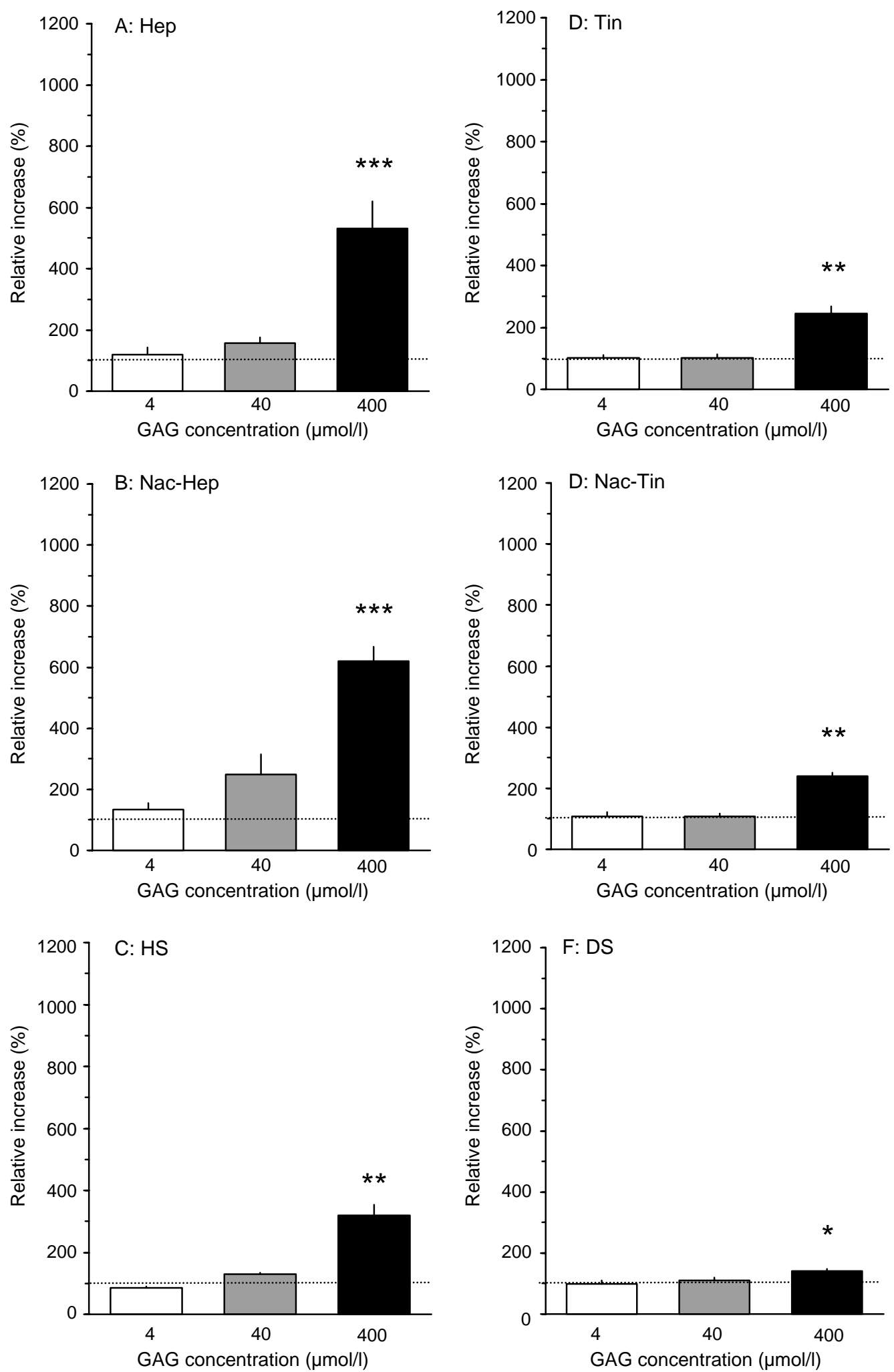

Figure 2 The relative increases in serum-free IGF-II after addition of six different GAGs. The dotted lines represent baseline levels after addition of buffer $(\sim 100 \%)$. All GAGs dose-dependently increased levels of free IGF-II $(P<0.005)$, however, with different potency $(P<0.0001)$ : at the highest doses, Hep and nac-Hep $\left(^{\star \star \star}\right)$ increased free IGF-II more potently than HS, Tin and nac-Tin $\left(^{\star \star}\right)$, which all increased free IGF-II more potently than DS $\left(^{*}\right)$. 
$(240 \pm 12 \%)$. Again, DS was the least potent GAG $(142 \pm 7 \%)$.

In contrast to free peptide levels, total IGFs-I and -II remained unchanged after addition of GAGs (data not shown). Similarly, the levels of intact IGFBPs as estimated by WLB were unaffected by addition of GAGs, when comparing the densities of the different bands. The only exception was nac-Hep, which in the highest dose $(400 \mu \mathrm{mol} / \mathrm{l})$ decreased the density of IGFBP-3, when compared with the other doses $(0,4$, and $40 \mu \mathrm{mol} / \mathrm{l}, P<0.005$ ) (data not shown).

\section{Study 2}

PS completely reversed the effect of heparin on free IGF-I levels (Fig. 3). This was true whether PS was added concomitant with heparin or at variable time intervals after addition of heparin.

\section{Study 3}

The IGF-I bioassay is believed to determine the sum of free IGF-I plus IGF-I being dissociated from the IGFBPs during incubation of serum with the IGF-IR transfected cells, and accordingly, bioactive IGF-I was significantly higher than free IGF-I in all study groups $(P<0.0001$; Table 1). Patients with T1DM had lower levels of all three circulating forms of IGF-I, when compared to controls $(P<0.05$; Table 1$)$. In women, bioactive and

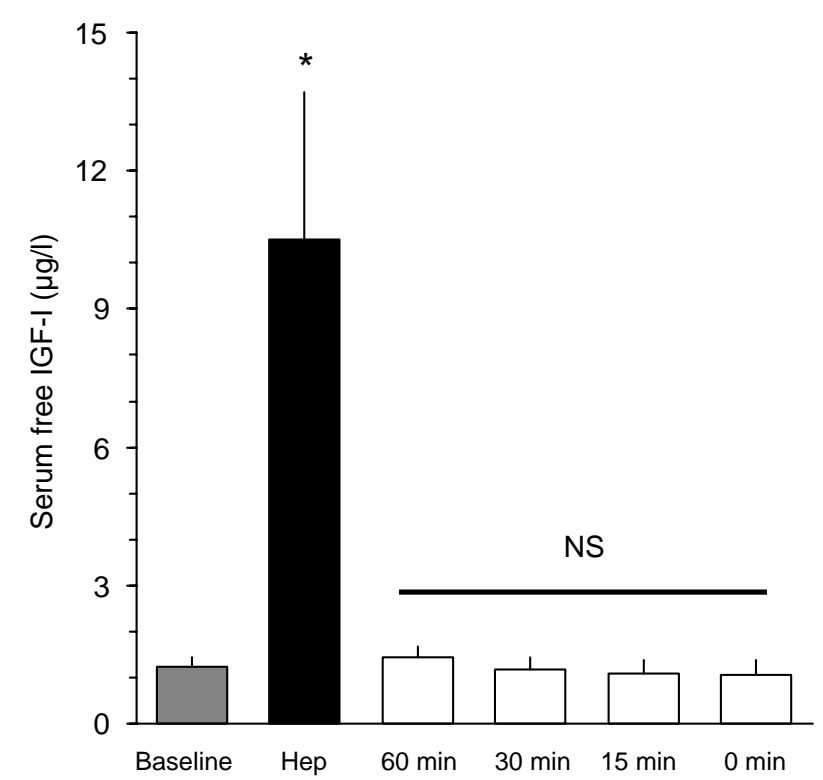

Figure 3 The effect of protamine sulfate (PS) $(5 \mathrm{~g} / \mathrm{l})$ on serum treated with heparin $(400 \mu \mathrm{mol} / \mathrm{l})$. The gray and black columns show levels of free IGF-I without (baseline) and with (Hep) addition of heparin respectively. The open columns show levels of free IGF-I in heparin-treated serum samples added PS at various time points prior to ultrafiltration. ${ }^{\star} P<0.0001$ when compared with baseline. Each column represents mean \pm S.E.M. of four serum samples. free IGF-I were increased during pregnancy $(P<0.05$; Table 1), whereas total IGF-I did not differ.

Heparin increased serum levels of free as well as bioactive IGF-I in all study groups $(P<0.0001$; Fig. 4). In controls, the absolute increase in bioactive IGF-I was larger than that of free IGF-I $(2.96 \pm 0.37$ vs $1.28 \pm$ $0.11 \mu \mathrm{g} / \mathrm{l}, \mathrm{P}<0.0006)$, and similar findings were made in patients with T1DM (change in bioactive vs free IGFI: $1.31 \pm 0.27$ vs $0.99 \pm 0.27 \mu \mathrm{g} / \mathrm{l}, P<0.008)$ and in pregnant women (change in bioactive vs free IGF-I: $5.35 \pm 0.54$ vs $2.78 \pm 0.43 \mu \mathrm{g} / \mathrm{l}, P<0.003)$. In post
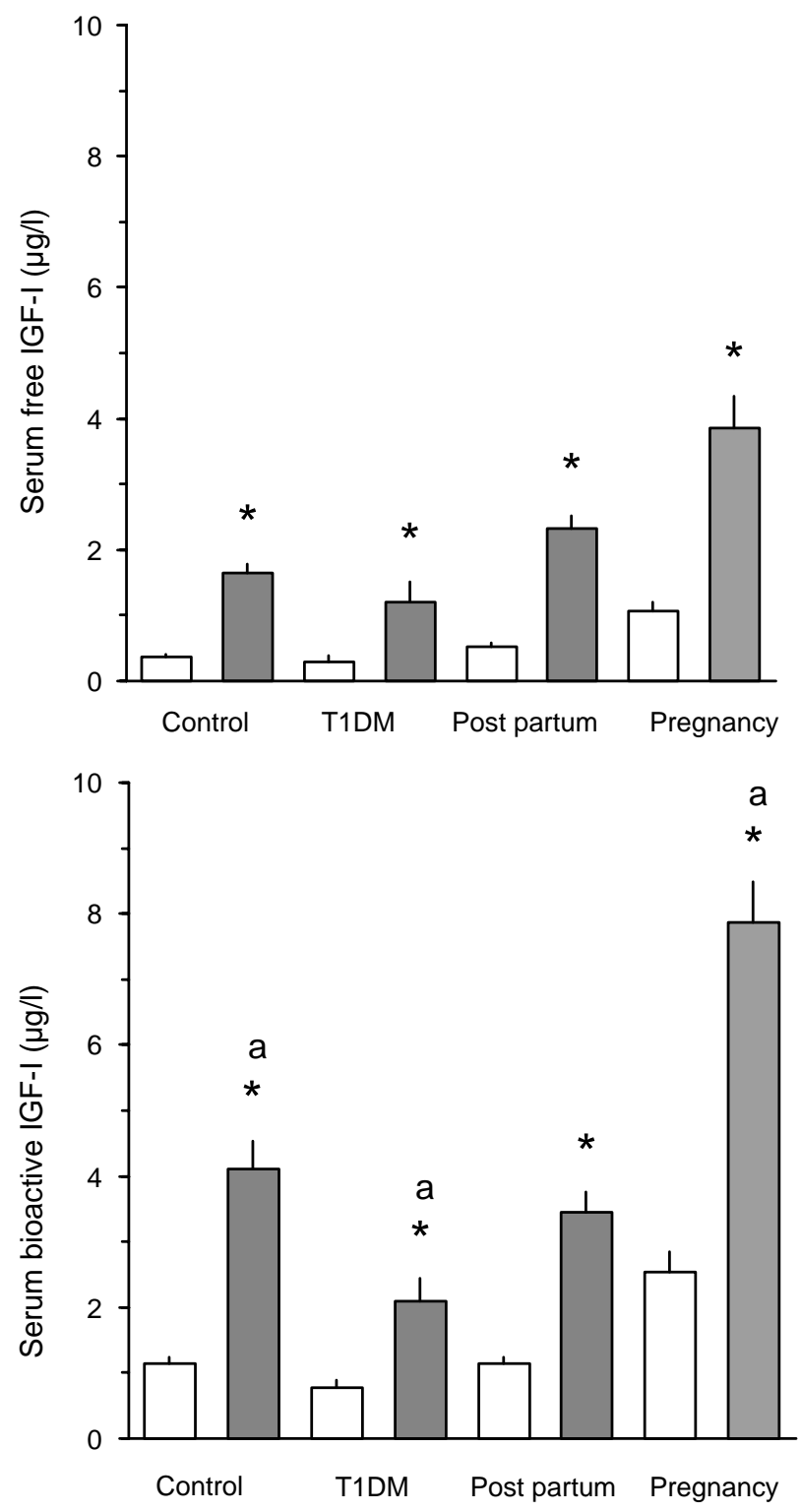

Figure 4 The effect of heparin on levels of free (upper panel) and bioactive (lower panel) serum IGF-I levels. ${ }^{*} P<0.0001$ when comparing samples before (white) and after (gray) addition of heparin. a: $P<0.05$ when comparing the absolute increase in free vs bioactive IGF-I within the same study group. Each column represents mean \pm S.E.M. of ten serum samples. 
partum women, bioactive IGF-I tended to increase more than free IGF-I, but the difference did not achieve statistical significance (change in bioactive vs free IGF-I: $2.31 \pm 0.24$ vs $1.80 \pm 0.15 \mu \mathrm{g} / \mathrm{l}, P=0.12$ ). Comparison of the stimulatory effects of heparin on free and bioactive IGF-I respectively in the four study groups showed that the largest change was seen in pregnant women, in whom the increase exceeded those observed in the other groups $(P<0.0001)$. In contrast to the observed changes in serum free and bioactive IGF-I, serum total IGF-I remained unaffected by heparin addition (data not shown).

Linear regression analysis was performed on pooled data from pregnant women, healthy controls and patients with T1DM $(n=30)$. Data from post partum women (which contained the same individuals as the pregnancy group) were not included, because it is not recommended to include more than one observation per individual in a regression analysis. The result of the linear regression analyses showed that serum levels of total, free, and bioactive IGF-I were strongly positively correlated before, as well as after, addition of heparin (Table 2).

\section{Discussion}

The present study showed that various GAGs, both with and without anti-coagulating activity, dosedependently increased serum free IGFs-I and -II, although with different potency, whereas serum levels of total IGFs and IGFBPs remained unchanged (with a single exception). Furthermore, it was shown that PS completely reversed the effect of heparin on free IGF-I. Although we did not measure changes in free IGF-II and heparin was the only GAG studied following co-incubation with PS, the latter finding indicates that the effect of GAGs on IGFBP-IGF interaction in general is fully reversible. Finally, heparin was able to increase in parallel serum levels of free and bioactive IGF-I in various patient samples, irrespective of the endogenous concentrations. However, heparin was particularly

Table 2 Linear regressions in pooled data from healthy controls, pregnant women and patients with T1DM $(n=30)$.

\begin{tabular}{lccc}
\hline Variables & $\begin{array}{c}\text { Heparin } \\
\text { addition }\end{array}$ & $\begin{array}{c}\boldsymbol{r}^{2} \boldsymbol{r}^{-} \\
\text {values }\end{array}$ & $\boldsymbol{P}$-value \\
\hline Free IGF-I vs bioactive IGF-I & No & $0.88 / 0.78$ & $<0.0001$ \\
Free IGF-I vs bioactive IGF-I & Yes & $0.81 / 0.65$ & $<0.0001$ \\
Free IGF-I vs total IGF-I & No & $0.77 / 0.59$ & $<0.0001$ \\
Free IGF-I vs total IGF-I & Yes & $0.87 / 0.76$ & $<0.0001$ \\
Bioactive IGF-I vs total IGF-I & No & $0.89 / 0.79$ & $<0.0001$ \\
Bioactive IGF-I vs total IGF-I & Yes & $0.79 / 0.63$ & $<0.0001$ \\
$\Delta$ bioactive IGF-I vs total IGF-I & Yes & $0.66 / 0.44$ & $<0.0001$ \\
$\Delta$ free IGF-I vs total IGF-I & Yes & $0.81 / 0.70$ & $<0.0001$ \\
$\Delta$ bioactive IGF-I vs delta free & Yes & $0.59 / 0.35$ & $<0.0001$ \\
IGF-I & & & \\
\hline
\end{tabular}

$\Delta$, the absolute change in levels of free or bioactive IGF-I following heparin addition. potent in serum from pregnant women, a finding which may relate to the extensive activity of IGFBP-3 proteases during pregnancy.

The six GAGs all significantly increased serum levels of free IGFs-I and -II in a dose-dependent manner, while the extractable peptide concentrations remained unaffected. WLB was used to evaluate the binding capacity of the IGFBPs in serum and with one exception no effect of GAG addition was observed. Thus, it appears that GAGs in general may serve to increase free peptide levels by releasing bound IGFs. The present data were obtained in serum and we cannot therefore conclude whether the increases in free and bioactive IGF levels were caused by liberation of IGF kept in binary and/or ternary complexes. However, both options appear to exist. The proximity of the HBD and the binding sites for IGF and ALS may explain that several different GAGs are reported to affect IGF:IGFBP as well as IGFBP-3:ALS complex formation $(13,14,22-25)$. Interestingly, despite their homogeneity, the IGFBPs appear to possess genuine differences in their response to GAGs: IGFBPs-3, -5 and -6 all show a reduced affinity for IGFs following GAG exposure, whereas the ligand affinity of IGFBP-4 appears to be unaffected. Data on IGFBP-2 are contradictory, but at least in some settings, IGFBP-2 has been reported to bind GAGs only in the presence of IGFs, while IGFBP-1 does not bind GAGs at all (23-25). Finally, GAGs appear to exert a larger impact on the binding of ALS to preformed complexes of IGF-I and IGFBP-3 than on the binding of IGF-I to IGFBP-3 (14). Taken together, it seems reasonable to assume that both binary and ternary IGF-complexes contribute to the observed increases in free and bioactive IGF-I as well as free IGF-II, but the relative contribution of the two IGF-fractions remains to be estimated.

The ability of the tested GAGs to increase serum levels of free IGFs-I and -II differed significantly. Apparently, the molecular weight affected the IGF releasing potency as tinzaparin (Innohep ${ }^{\circledR}$ ) and nactinzaparin were less potent than heparin and nacheparin DS was the least potent GAG, though its molecular weight is high. This observation is probably related to the low degree of sulfation as the charge density is considerably lower in DS as compared to heparin. In addition, the backbone structure of the GAGs may be as important as galactosamine is present in DS, instead of glucosamine. There was no difference between the IGF-releasing potency of the two low molecular weight heparins (tinzaparin and nac-tinzaparin), and a similar observation was made when comparing the potency of nac-heparin and heparin. As heparin sulfate, which has no anti-coagulant activity, was also quite potent, we conclude that the ability of GAGs to release IGFs-I and -II is not related to their anti-coagulant activity.

It has been suggested that in vivo, IGF-I bioactivity is composed of the sum of free IGF-I plus IGF-I being 
released from the IGFBPs at the site of the IGF-IR (i.e. readily dissociable IGF-I) (26), and in accordance with this idea, serum levels of bioactive IGF-I were significantly higher than levels of ultrafiltered serum free IGF-I in all four study groups. In addition, heparin caused a significantly larger increase in bioactive than free IGF-I in all groups except non-pregnant women. The reason that non-pregnant women differed in this respect remains unknown, but we speculate that it may be due to pregnancy-related changes in the circulating IGF-system, which may still be present 5 weeks post partum. If heparin only increased levels of free IGF-I through competitive binding, we would expect similar increases in free and bioactive IGF-I. Since this was not the case, it may be speculated that heparin not only serves to liberate IGF-I from its binding proteins, but also increase the fraction of readily dissociable IGF-I, most likely by lowering the ligand affinity of the IGFBPs as previously reported $(13,14)$.

Although levels of free and bioactive IGF-I were strongly correlated before, as well as after, addition of heparin, a more detailed analysis showed that the greatest increases in serum free and bioactive IGF-I were observed in pregnant women. Pregnancy is characterized by an extensive IGFBP-3 proteolytic activity (27), which is easily detectable as early as after 8 weeks after gestation, where $\sim 70 \%$ of serum IGFBP-3 has been degraded (20). Enzymatic degradation of IGFBP-3 has been reported to cause a tenfold reduction in its affinity for IGF-I (28), a finding which may explain that pregnant women have increased serum levels of free and bioactive IGF-I, as also observed in the present study $(20,29)$. Furthermore, IGFBP-3 proteolysis appears to render IGFBP-3 more susceptible to heparin. Accordingly, serum incubated overnight at $37^{\circ} \mathrm{C}$ and hence affected by proteolytic enzymes in serum was much more sensitive to the effect of heparin than serum analyzed without overnight incubation (22).

We included patients with T1DM, because their circulating IGF-system is markedly different, when compared to pregnant women. First, T1DM is associated with subnormal levels of total and free IGFs $(21,30)$; secondly, IGFBP-3 proteolysis does not appear to be a major issue, at least not in the present cohort of patients, who have all been on long-term insulin treatment $(21,30)$; an exception is newly diagnosed and hence poorly controlled patients, in whom IGFBP-3 proteolysis appears to be upregulated (31). Still, despite low endogenous levels of IGF-I, heparin was able to increase serum levels of free and bioactive IGF-I in the diabetic group, and again the absolute increase in IGF-I bioactivity was significantly larger than that of free IGF-I. On the other hand, the observed increases following heparin were less marked than in healthy controls, indicating that the ability of heparin to increase free and bioactive IGF-I is dependent on total IGF-I levels, as also indicated by the regression analyses.
The present data support the hypothesis that GAGs, through their impact on ALS-IGFBP-IGF interaction, participate in the regulation of IGF-I bioactivity $(5,13$, 14). This is likely to occur at different sites, affecting the IGF-system in the circulation as well as in the peripheral tissues. GAGs attached to endothelial cells may serve to increase the trans-endothelial transport of IGFs-I and -II, whereas GAGs localized in the ECM may serve to increase free IGF-I levels near the site of the IGF-IR. However, at the time of writing, there are only very sparse data on the effect of GAGs on IGF-I bioactivity in vivo, and these observations do not allow us to extrapolate our in vitro findings to the in vivo situation (32-34).

In conclusion, GAGs possess the ability to increase serum levels of free and bioactive IGF-I in vitro without affecting total IGF-I or IGFBP levels. Of note, the IGF-I liberating effect was independent of the anti-coagulating activity of the GAGs, and as judged from the ability of PS to neutralize the effect of heparin, it was fully reversible. We speculate that the non-anti-coagulating GAGs could be used as IGF-I displacers, serving to increase the activity of the endogenous IGF-system in catabolic conditions with upregulated IGFBPs such as in uremia, T1DM, and anorexia nervosa $(35,36)$.

\section{Acknowledgements}

This study was supported by grants from The Danish Research Council for Health and Disease, The Novo Nordisk Foundation, Clinical Institute at University of Aarhus and the Family Hede-Nielsen Foundation. We are indebted to I Christensen, K Nyborg Rasmussen, K Mathissen, S Sørensen and I Bisgaard for their skilled technical assistance. Dr Christian Skjærbæk, Medical Research Laboratories, Aarhus University Hospital is thanked for providing samples from pregnant and post partum women.

\section{References}

1 LeRoith D, Bondy C, Yakar S, Liu JL \& Butler A. The somatomedin hypothesis: 2001. Endocrine Reviews 2001 1 53-74.

2 Pollak MN, Schernhammer ES \& Hankinson SE. Insulin-like growth factors and neoplasia. Nature Reviews Cancer 20047 505-518

3 Hwa V, Oh Y \& Rosenfeld RG. The insulin-like growth factorbinding protein (IGFBP) superfamily. Endocrine Reviews 19996 761-787.

4 Firth SM \& Baxter RC. Cellular actions of the insulin-like growth factor binding proteins. Endocrine Reviews $20026824-854$.

5 Payet LD, Firth SM \& Baxter RC. The role of the acid-labile subunit in regulating insulin-like growth factor transport across human umbilical vein endothelial cell monolayers. Journal of Clinical Endocrinology and Metabolism 20045 2382-2389.

6 Firth SM, McDougall F, McLachlan AJ \& Baxter RC. Impaired blockade of insulin-like growth factor I (IGF-I)-induced hypoglycemia by IGF binding protein-3 analogue with reduced ternary complex-forming ability. Endocrinology 20025 1669-1676. 
7 Zapf J, Hauri C, Futo E, Hussain M, Rutishauser J, Maack CA \& Froesch ER. Intravenously injected insulin-like growth factor (IGF) I/IGF binding protein-3 complex exerts insulin-like effects in hypophysectomized, but not in normal rats. Journal of Clinical Investigation 199595 179-186.

8 Chan SS, Twigg SM, Firth SM \& Baxter RC. Insulin-like growth factor binding protein-3 leads to insulin resistance in adipocytes. Journal of Clinical Endocrinology and Metabolism $2005126588-6595$.

9 Sasisekharan R, Shriver Z, Venkataraman G \& Narayanasami U. Roles of heparan-sulphate glycosaminoglycans in cancer. Nature Reviews Cancer 20027 521-528.

10 Kalluri R. Basement membranes: structure, assembly and role in tumour angiogenesis. Nature Reviews Cancer 20036 422-433.

11 Clemmons DR. Use of Mutagenesis to probe IGF-binding protein structure/function relationships. Endocrine Reviews $20016800-817$.

12 Bach LA, Headey SJ \& Norton RS. IGF-binding proteins - the pieces are falling into place. Trends in Endocrinology and Metabolism 2005 $5228-234$.

13 Arai T, Parker A, Busby WJ \& Clemmons DR. Heparin, heparan sulfate, and dermatan sulfate regulate formation of the insulin-like growth factor-I and insulin-like growth factor-binding protein complexes. Journal of Biological Chemistry $199426920388-20393$.

14 Baxter RC. Glycosaminoglycans inhibit formation of the $140 \mathrm{kDa}$ insulin-like growth factor-binding protein complex. Biochemical Journal 19903 773-777.

15 Frystyk J, Dinesen B \& Ørskov H. Non-competitive time-resolved immunofluorometric assays for determination of human insulinlike growth factor I and II. Growth Regulation 1995 4 169-176.

16 Frystyk J, Skjærbæk C, Dinesen B \& Ørskov H. Free insulin-like growth factors (IGF-I and IGF-II) in human serum. FEBS Letters 19942 185-191.

17 Chen JW, Ledet T, Ørskov H, Jessen N, Lund S, Whittaker J, De Meyts P, Larsen MB, Christiansen JS \& Frystyk J. A highly sensitive and specific assay for determination of IGF-I bioactivity in human serum. American Journal of Physiology: Endocrinology and Metabolism 20036 E1149-E1155.

18 Frystyk J, Ivarsen P, Skjærbæk C, Flyvbjerg A, Pedersen EB \& Ørskov H. Serum-free insulin-like growth factor I correlates with clearance in patients with chronic renal failure. Kidney International $199962076-2084$.

19 Flyvbjerg A, Mogensen O, Mogensen B \& Nielsen OS. Elevated serum insulin-like growth factor-binding protein 2 (IGFBP-2) and decreased IGFBP-3 in epithelial ovarian cancer: correlation with cancer antigen 125 and tumor-associated trypsin inhibitor. Journal of Clinical Endocrinology and Metabolism 1997 7 2308-2313.

20 Skjærbæk C, Frystyk J, Ørskov H \& Flyvbjerg A. Free IGF-I, IGFBP1 , and the binary complex of IGFBP-1 and IGF-I are increased during human pregnancy. Hormone Research 20045 215-220.

21 Frystyk J, Bek T, Flyvbjerg A, Skjærbæk C \& Ørskov H. The relationship between the circulating IGF system and the presence of retinopathy in type 1 diabetic patients. Diabetic Medicine 20034 269-276.

22 Clemmons DR, Underwood LE, Chatelain PG \& Van Wyk JJ. Liberation of immunoreactive somatomedin-C from its binding proteins by proteolytic enzymes and heparin. Journal of Clinical Endocrinology and Metabolism 198356 384-389.
23 Arai T, Busby W Jr \& Clemmons DR. Binding of insulin-like growth factor (IGF) I or II to IGF-binding protein-2 enables it to bind to heparin and extracellular matrix. Endocrinology 199611 4571-4575.

24 Russo VC, Bach LA, Fosang AJ, Baker NL \& Werther GA. Insulinlike growth factor binding protein-2 binds to cell surface proteoglycans in the rat brain olfactory bulb. Endocrinology $1997114858-4867$.

25 Marinaro JA, Neumann GM, Russo VC, Leeding KS \& Bach LA. O-glycosylation of insulin-like growth factor (IGF) binding protein6 maintains high IGF-II binding affinity by decreasing binding to glycosaminoglycans and susceptibility to proteolysis. European Journal of Biochemistry 200017 5378-5386.

26 Juul A, Holm K, Kastrup KW, Pedersen SA, Michaelsen KF, Scheike T, Rasmussen S, Müller J \& Skakkebæk NE. Free insulin-like growth factor I serum levels in 1430 healthy children and adults, and its diagnostic value in patients suspected of growth hormone deficiency. Journal of Clinical Endocrinology and Metabolism $1997 \mathbf{8}$ 2497-2502.

27 Giudice LC, Farrell EM, Pham H, Lamson G \& Rosenfeld RG. Insulin-like growth factor binding proteins in maternal serum throughout gestation and in the puerperium: effects of a pregnancy-associated serum protease activity. Journal of Clinical Endocrinology and Metabolism 19904 806-816.

28 Lassarre C \& Binoux M. Insulin-like growth factor binding protein3 is functionally altered in pregnancy plasma. Endocrinology 1994 $1341254-1262$.

29 Blat C, Villaudy J \& Binoux M. In vivo proteolysis of serum insulinlike growth factor (IGF) binding protein-3 results in increased availability of IGF to target cells. Journal of Clinical Investigation $1994932286-2290$.

30 Frystyk J. Free insulin-like growth factors - measurements and relationships to growth hormone secretion and glucose homeostasis. Growth Hormone and IGF Research $20045337-375$.

31 Bereket A, Lang CH, Blethen SL, Fan J, Frost RA \& Wilson TA. Insulin-like growth factor binding protein-3 proteolysis in children with insulin-dependent diabetes mellitus: a possible role for insulin in the regulation of IGFBP-3 protease activity. Journal of Clinical Endocrinology and Metabolism 199580 2282-2288.

32 Gorio A, Vergani L, De Tollis A, Di Giulio AM, Torsello A, Cattaneo L \& Muller EE. Muscle reinnervation following neonatal nerve crush. Interactive effects of glycosaminoglycans and insulin-like growth factor-I. Neuroscience 19984 1029-1037.

33 Mnich Z \& Palka J. Heparin-induced modulation of insulin likegrowth factor-I action on glucose level in control and fasted rats. Medical Science Monitor 20011 42-48.

34 Marshall SM, Hansen KW, Østerby R, Frystyk J, Ørskov H \& Flyvbjerg A. Effects of heparin on renal morphology and albuminuria in experimental diabetes. American Journal of Physiology: Endocrinology and Metabolism 19961 E326-E332.

35 Sakai K, Lowman HB \& Clemmons DR. Increases in free, unbound insulin-like growth factor I enhance insulin responsiveness in human hepatoma G2 cells in culture. Journal of Biological Chemistry 200216 13620-13627.

36 Roelfsema V, Lane MH \& Clark RG. Insulin-like growth factor binding protein (IGFBP) displacers: relevance to the treatment of renal disease. Pediatric Nephrology 20007 584-588.

Received 10 March 2006

Accepted 5 May 2006 